\title{
POLITENESS OF SPEAKING IN WATAMPONE COMMUNITY (Ethnographic Research Communications In Kabupaten Bone, Sulawesi Selatan)
}

\author{
Muh. Safar*, Sabarti Akhadiah** \\ STKIP Muhammadiyah Bone, Indonesia* \\ Universitas Negeri Jakarta, Indonesia** \\ safarstkip73@yahoo.com*
}

\begin{abstract}
This study aimed to describe in detail about politeness of speaking in Watampone community. The focus of this research is politeness of speaking in Watampone community. The subfocus is politeness in terms of the principles of cooperative and cultural aspects of Watampone community. This study was a qualitative research by using ethnographyof communication method. The technigues and procedures of data collection were used such as observation, recordings and transcrips, and interviews. Based on data analysis, the politeness of speaking in Watampone community used in formal in situation the first Watampone community apply the principles of cooperative and second, cultural aspects can be seen verbal and nonverbally.
\end{abstract}

Keywords: politeness of speaking, watampone community, and ethnography of communication.

Watampone community in interacting uses two languages, Indonesian and Bugis language. Both are used as a means of communication in formal and informal situations. The use of Indonesian and Bugis language will utter with politeness patterns based on Bone's culture, at Watampone. Politeness is self-control and social control. In Bugis language, it is called pangngaderen or ampe madeceng 'polite behavior'. The characters of polite behavior will fit into the certain community social (socially correct), or the acceptability of behavior in the context of social interaction. In assessing Bone or Bugis language, local language of Makassar, is related to linguistic phenomenon from the point of politeness that cannot be separated from review the meaning of utterances attributed to the event and explained the situation, and the interpretation of the meaning associated with the norms and principles of the culture itself.

Along with the development of globalization, Bone society, especially Watampone society has moved away from decency and moral background. That is, people use politeness in practical life just want very practical. They do not pay attention to the rules of language and linguistic politeness in everyday in life. They only pay attention to the effectiveness and speed, because they are always being chased by time. They pay less attention to the element of politeness in language that is very important. In fact, politeness language becomes a very important thing to discuss with the phenomena that occurs in the community. Reformation period has run almost 16 years that it is marked by enthusiasm of speech of Indonesia's community. They are freedom to speech. The freedom of speech sometimes ignores the politeness language. For instance, it can be seen in the situation and the atmosphere of the demonstration or rally. These things could have been avoided if it is guided by the principles of politeness in communicating. 
In Bugis ethnic's culture, particularly Bugis of Watampone, it seems politeness phenomenon that has been reviewed before. It can be examined through a comprehensive meaning of "siri". Cultural values that are elaborated in three subsystems of culture, namely sipatangngari (consultation), sipakaraja (mutual respect), sipakatau (glorify each other), (Mattulada, 1997: 17). Application of politeness will reduce misunderstandings between the speaker and hearer so that communication can take place in harmony and avoid conflicts.

Brown and Levinson defined politeness in speaking as a system that is applied in face to face interactions to maintain it (Brown and Levinson, 2006: 331). This definition implies that an action or utterance in an interaction has the potential to embarrass the speaker, condescending pride, or injurious honor. Threats can also be experienced by the speaker himself if interlocutors responded to an action that is less mannered with the same action. Thus, it is possibly to loss honor that can be experienced by all those people who are actively involved in a verbal interaction. Kinds of threats are namely the negative image and positive image.

Negative image refers to any person who wants to be rewarded with the letting free to do actions or to do something necessarily. While positive image refers to any person who is desirous that what he was doing, what he has or what the values he believed (as a result of what was done and had it) recognized other people as a good thing or a fun which is commendable and so on.

From the definition above, it can be concluded that politeness is a way, effort or action taken by a speaker on their own initiative do with the other person in order to have good relationship. Thus, the initiative maintains the quality of interpersonal relationships, it arises from the speakers. However, because the speaker and hearer in an interaction always switch roles, they also have the initiative to keep the feeling that is involved in an interaction. Politeness language in this study refers to Brown and Levinson's definition because of the theory is as the basis of communication ethnographic studies in politeness language in Watampone.

In general, according to Grice (1975: 49) said that the principles of cooperation includes four categories: quantity, quality, relation, and manner.

a. Quantity category, quantity category related to the quantity of information to be provided by the rules: a) make your contribution is informative and required (for the current purposes of interaction) and b) do not make your contribution more informative than necessary (but it cannot be said that more informative is violation of the principle of cooperation but merely it waste of time).

b. Quality category, the quality category is regarded as a super maxim "Your contribution is right" with the rules: a) do not say what you believe is wrong and b) do not say if you do not have sufficient evidence.

c. Relation category. "Make relevant". Although the maxim is short, but there must be a formulation that regard to a number of issues with focusing to the question of what types and focusing on the relevance that may exist, how the shift process in turning to speak, how facts which allow or the fact is legally.

d. Manner category. it not means to regulate what is said but how should be said. That is, the concern of category is how the implementation of the utterances that is uttered by participants in interaction. Based on this cooperation, the principle should be applied in the speech. The principle of cooperation is aimed to describe the action of speaker and hearer in the interaction. 
Culture is a lifestyle or a signs of community. Culture is complex, abstract, and spacious. Many cultural aspects also determine the communicative behavior. Elements of socio-cultural spread and include many social activities of human (Mulyana and Rachmat, 2006: 25). Thus, culture provides a coherent framework for organizing the activities of a person and allowing predicting the behavior of others.

Brown defined that culture is as a way of life. Cultural related to context of humans' think, feel and others (Brown, 2000: 176). Furthermore, Brown (2000: 177) said that the culture can also be defined as ideas, habits, skills, and devices that characterize a group of people within a certain time period. However, culture is more than those parts. Brown also said that the facts or the presence of people without a culture that reflects to fill the biological and psychological needs of each person. Thus, Brown's concept is about culture is everything that exists and grows in the middle of the community in the form of ideas, ideas, skills, and devices. Eventhough, the biological and psychological needs is as well as reflecting the prevailing culture in a society.

Language and culture are the two factors that are interlinked and inseparable. Learning a language means learning the language's culture (Sidi and Achmad, 2003: 35). Language is a tool for expressing ideas, thoughts, and feelings. Suparno stated that the language and the study of language cannot be separated from any phenomenon becaues it involves human life in various domains (Suparno, 2003: 325). This statement suggests that the study of language is indirectly implemented the cultural values in their spoken.

Kramsch (1998: 117) argued the relationship between language and culture, that the language expresses cultural reality. However, every member of society or a social group not only express their thoughts, but also create experiences through language. In this case, members of the society give the meaning of experience through selected media in order to communicate each other. For example, talking over the phone, face to face, write a letter or send an e-mail, read the newspaper or interpret a graph or chart.

How to someone using the media, such as spoken, written and visual contained the meaning that will be understood in the group which they belong. Kramsch exemplifies the high and low voice, accent, speaking style, body language, and facial expressions. All those parts are through verbal or nonverbal aspects of language that would encompass cultural reality. Kramsch's concept illustrates that the relationship between language and culture is closely related because it uses of the voice, accent, speaking style, body language, and facial expressions that show an association with a person's cultural background.

The term ethnography of communication is expressed by Emzir (2009: 144) is a social science research methods. This study strongly believe in closure (up close), personal experiences, and participation is possible, not just observations, the researchers were trained in the art of ethnography.

The theory is used in this study is the ethnography of communication theory that is developed by Dell Hymes and Saville-Troike. An assumption about the language and the situation is the unity that cannot be separated (Hymes, 1972: 58). Each speech has always been associated with the situation. Next, Dell Hymes argued that the components associated with the interaction, namely: message form , the content of the message, setting, scene, speaker or sender, addressor, listener or receiver or audience, purpose-results, goals objectives, key, channel, forms, the 
norms of interaction, interpretation of norms, and the genre that is namely with speaking.

This study aims to gain a deep understanding of politeness language in Watampone community that includes: 1) politeness terms of the principles of cooperation in Watampone community and 2) politeness in terms of cultural aspects in Watampone community.

\section{METHOD}

This study was conducted in Watampone, Bone regency, exactly about the formal activities in the meeting at the regent's office, education office, and Tenriawaru hospital. While, informal activities are concentrated in the central market of Watampone. This study was about four months. It started from January to April 2014.

This study is a qualitative research of ethnography of communication method based on Dell Hymes theory that was developed by Saville-Troike (Saville-Troike, 2003: 28).

The data of the study is the politeness language of Watampone community, such as words that carried out during participatory in interaction. Source of data in this research is Watampone community about politeness language that occurs in the interaction in formal activities, for instance: Bone regent's office, education office, Tenriawaru hospital.

The technique of collecting data used Ethnographic method were observation, participant observation and interviews, formal and informal interviews. Interviews were conducted with informants as a data source. Procedure of data analysis is performed by Dell Hymes theory that is developed by Saville Troike, such as, encoding, re-evaluation, analyzing every aspect, interpreting and meaning.

\section{RESULTS}

Results of the study were associated with politeness in terms of the principle of cooperation. It is described below.

In application of the principle of cooperation, researcher clarified based on the speech that is spoken by the participants in a formal situation, such as, Bone regent's office, education office, hospital, and the central market of Watampone. Based on data analysis, it is found that participants apply and violate the principles of cooperation by Grice. First, the description maxim of quantity in formal and informal conversation in Watampone related to the quantity of information that it is submitted by the speakers and required each participant to provide enough information or as required of the hearer. It means that to achieve the implementation of the maxim of quantity in formal and informal conversation with sufficient information, or as much as needed hearer. However, if the speech in formal and informal conversation contain redundant information, it can be categorized as a violation of the maxim of quantity. Every utterance in quantity maxim uttered with more concise and do not deviate to the value of truth. 
Utterances between speaker and hearer contain more maxim of quantity. In addition, the utterance that is uttered sometimes appropriate with the maxim of quantity and sometimes violation of maxims of quantity. This is caused by the presence of something that is spoken more informative than requested. It is also common happened in formal situation on education offices. For example, speakers discussed about the implementation of the national exam coaching for students of class IX, nevertheless, speaker provides explanation too long so the hearer does not understand the explanation that it has given. Similarly happening in the sale and purchase transaction, the buyer gives the explanation too wordy or too long to the seller so the seller feels confused in determining the choice of goods to be bought. Politeness language looks at the use of the word -ki from the letters eloki and anuki.

Second, the descriptions of maxim of quality in formal and informal conversation have been applied. It means that both speaker and hearer provide information based on actual fact. This is consistent with the statement from Wijaya (1996: 48), he stated that the contribution of the information should be based on sufficient evidence. So that integrity or honesty is very important in realizing the maxim of quality. Violations of the maxim of quality are caused by the inadequate information that is spoken. Although, it has been applying the maxim of quality, there is still violation. For example, the moderator said, "Suppose that 110 people how many times?" Suddenly one participant said "20,000". The answer only offers little information because it is only based on a prediction without careful calculation of the activities consumption. However, after calculated accurately, the secretary of the education department said, "25,000". In reflecting on buying and selling transactions, in the center market Watampone, for example, the buyer bargains about 40 thousand but the seller says he could not because he does not get profit so buyers leave the place. Not too long, the seller direct says "Eeeh take it". This indicates that the seller has violated the maxim of quality in interaction. Politeness language, both formal and informal situation, looks at the use of word "Nak" that is spoken by the speaker to the hearer.

Third, formal and informal interaction or conversation in Watampone community has applied the maxim of relevance if the contributions are made by the participants completely required. While, if the contribution is not relevant to topic that is being discussed, then, it is categorized as a violation of the relevance maxim. Utterances between the speaker and the hearer sometimes violations maxim of relevance. It is caused by the effort of speakers to provide information that does not have a relationship on the topic. Moreover, the researcher assumes that such information is appropriate given to audience at the meeting as the socialization of topic that being discussed. Politeness language can be seen in the utterance, "Puang, I sing solo, thank you, thank you Puang". The use of the word "Puang" is a form of politeness words to the hearer.

Fourth, the description of maxim of manner, a formal interaction, in Watampone community related to how way the participant speaks. This means that the application of the maxim of ways will achieve in formal interaction when the speaker and hearer have a conversation with a predetermined manner that is not vague, equivocal, and not excessive. Thus, the speaker is able to interpret the words used by the hearer said based on contexts. In the formal and informal interaction or conversation have been applying the maxim of ways as any spoken utterances properly and accordance with the indicators proposed by Grice. Politeness language 
can be seen from the utterance, "Saya tanyaki karena kelompok komplit?" ("I asked you that the team is complete?”) and “Apa alasanta?” ("What is your reason?”). The words - $\mathbf{t a}$ and $-\boldsymbol{k i}$ is as sign of politeness languuage in Watampone community.

Politeness language is viewed from the aspect of culture in Watampone community, it can be divided into two verbal and nonverbal communication. Verbal communication includes: 1) accent, Watampone community in interacting attempt to use sound pressure medium and sometimes high. In addition, there is a special emphasis on a word by adding "-mi" in the word "adami" ("Anyone”), "-ji" in the word "dikumpulji" ("Collect it”). The utterance "adami" in which there is the addition of "-mi" in the Indonesian language should not be necessary. Because, it is Watampone culture, when talking both in formal and informal situation, that accents are sometimes using it. Accent "-mi" is attached to the word "adami" ("Anyone”) as a confirmation position; 2) The use of the words strongly bonded by the local customs, customary politeness, and the situation. Watampone community uses several greeting words in conversation, for instance Puang, Kak, Ndi, Nak, Bu, and $P a k$, although those are not necessarily used. Those greeting words used to express reverence and or familiarity to the hearer. The greeting words $\mathrm{Kak}, \mathrm{Nak}$, and $\mathrm{Bu} / \mathrm{Pak}$ are absorbed from greeting words in Indonesian which was originally greeting words belonging kinship term. However, Bugis Watampone’s speaker already used to greet his hearer or partner, although he used Bugis language. The greeting words is the most prominent using in the Bone culture is "Puang". That can be seen in utterance, Bagus ubinya itu Puang (That's good ..., Puang). 3) The politeness vocabulary marker means here is the use of words "tabe" (Excuse me) and "iye” (Yes). These words usually reserved to the hearer at the higher status. Although, sometimes it uses to the someone new as the psychological factors to be polite to other people who called "mappakalebbi” ("glorify") or "mappakaraja” ("appreciate"). For example, "Iye, hanya saya di kasih pindah di sini" (Yes, only me who moved in here). The words "Iye" has same meaning with "Yes". While, the word "tabe", for example, "Tabe, disini jurinya 3 orang yaitu ibu Martina, Pak Samad, dan Pak Rahman” (Excuse me, the jury is Mrs. Martina, Mr. Samad, and Mr. Rahman). The word "tabe" has the same meaning with "Excuse me" (permission). It means that before the speaker opened the conversation, he used the word "tabe" as a form of respect to the hearer. 4) Watampone community knows some meaningful of honorifics to show the linguistic politeness formulas. The honorifics such as, -ki, -ta, and -in. The honorifics, $-k i$, $-t a$, and -in, is a adding that serves as a constituent in the conversation that refers to people who talk or act as speaker. It could be said that the honorifics is a word of greeting as a second person (pronoun). The use of honorifics showed a politeness formula or a form of respect. This can be seen in the utterance, “Janganki bicara dulu yang itu karena bkan kewenanganta” (Stop talking, it's none our bussiness). The honorifics "-ki" serves as a homage and a familiarity that is indicated by the speaker to the hearer. While, the honorifics "-ta" on "kewenanganta" is used to show the kinship between speaker and hearer.

Moreover, the cultural aspects that concern to nonverbal communication, namely: 1) kinesik, for the Watampone community, body movement is one of their culture that still remain valid. Similarly, when someone walked and crossed in front of the person who involved in conversation, so the hearer still conduct his body to bent slightly while saying "tabe" or one hand put forward as one of the forms to respect the speakers. Another ways is the movement stands. it is seen in formal 
situations when the speaker asked one participant to answer questions, suddenly, the participant intended stood up and answered speaker's questions. it is done by the hearer because it indicates that the speaker at that moment was standing on the podium and higher positions than the hearer, so consciously the hearer answered by standing while he nodded. Kinesik or the use body language to interact naturally is adapted to the conditions of society and to whom they are talking to. Accuracy using body language is possibly used it in interacting to facilitate the speaker to convey something from the hearer. However, errors in the use of body language can be a problem in self-speaker; 2) kinesthetic. The movement body bents while a movement of the hand forward is kinesthetic. As happened at the meeting of the nursing committee is between the Head of HR and supervising students. The utterance between Head of HR and supervising students based on the data, the Head of HR said, "Jadi tabe" (So, tabe) while holding supervisor's hands. The use of body language by holding and squeezing hands supervisor indirectly showed to reprimand the supervisor's by using the phrase. It is done in order to be better maintain the hearer's feeling not to be known by the other participants.

Based on the description above, kinesthetic as one whose body language is sometimes considered to be the right thing to do and sometimes not the right thing to do. Doing something error with no consideration to the condition, it is possible would have a negative impact.

\section{DISCUSSION}

In the course of speaking, speaker and hearer should be aware that there are rules that govern its actions, the use of language, and interpretation of the acts and the partners' saying. In interaction activity, there is cooperative principle that the speaker and hearer should be done in order to the communication process runs well. The important role of the principle of cooperation is proposed by Yule. Yule (1996: 37) argued that the principle of cooperation, speakers should contribute to conversations as appropriated when the conversation happened. It aims to determine the realization of the partners' saying in conversation. Therefore, the speaker is always trying that his contribute always relevant to the context, clear, and easy to understand, solid, and quick and always on the issue. So, it is not spend time.

Based on Grice's the principles of cooperation theory that has been applied in this research is the application of the maxim of quantity, quality, relevant, and ways. In spite of the application of the principle of cooperation is also a violation of the principle of cooperation.

In accordance with the findings of researchers that one of reciprocal efforts made by the speaker and hearer in advance to minimize the threat, other than the use of indirect speech acts is the use of speech that signed by the choice of diction and variations formal utterance of Bugis community, sociocultural background (Watampone), as a form of politeness. Variation of utterance refers to the activity in interacting. In formal situations which are directly governed by the rules of the use of speech. Kartomiharjo (1988) said that variations in speech is a reflection of social factors and cultural and bounded by rules and norms. As the results of research that has been conducted, it shows that the language of Watampone community often use variations of Bugis language speech. It can be seen with the use of Bugis accent like 
$j i$ and $m i$, the use of greeting forms like Puang, the use of honorifics ta and $k i$, the use of vocabulary as social markers such as, iye and tabe. In addition, the use of nonverbal language is such as kinesik and kinesthetic.

\section{CONCLUSION}

Politeness in terms of the principle of cooperation, Watampone community in formal situations has been applying the Grice's principles of cooperation, namely the application of the maxim of quantity, quality, relevant, and manner in each speech with the addition of honorifics $t a$ and $k i$. The fourth kind of maxim has been applied in various situations, so that communication runs well. Although, Watampone community has applied the maxim, however, many speechs also contained a violation of maxims. It happens because of the ignorance of the speaker in speaking. In addition, there is a tendency of speakers to exploit the situation to convey different information based on the condition that the presence of hearer at the time then it is very appropriate to convey information related to the maxim of relevance.

Politeness is in terms of cultural aspects. Cultural aspects related to verbal communication, namely: accents, greeting, honorifics, while nonverbal communication is kinesik and kinesthetic. Watampone community in formal situations in interacting sometimes uses sound pressure such as medium, high and vice versa. The second aspect is the use of culture greeting. The third cultural aspect of verbal communication is the use of honorifics. Watampone community knows some meaningful of honorifics to show the formula of linguistic politeness. The fourth is vocabulary as social marker.

Cultural aspects of nonverbal communication are kinesik and kinesthetic. Kinesik or body language is very important to understand the speaker and hearer to achieve good communication.

\section{REFERENCES}

Brown, H. Douglas. 2000. Principles of Language Learning and Teaching. Fourth Edition. White Plains, NY: Longman.

Brown, Penelope and Stephen C. Levinson. 2006. Politteness: Some Universal in Language Usage, dalam Adam Jaworski dan Nikolas Coupland (Eds.), The Discourse Reader: Introduction (Second Edition). London: Routledge.

Deddy Mulyana and Jalaluddin Rakhmat. 2006. Komunikasi Antarbudaya: Panduan Berkomunikasi dengan Orang-Orang Berbeda Budaya. Bandung: Remaja Rosdakarya.

Emzir. 2009. Metodologi Penelitian Pendidikan: Kuantitatif dan Kualitatif. Jakarta: PT Raja Grafindo Persada. 
Grice, H.P. 1975. Logic and Conversation, Syntax and Semantics, Speech Act 3. New York: Academic Press.

Hymes, Dell. 1996. Ethnography. Linguistics, Narrative Ineguality: Toward an Understanding of Voice. London: Taylor and Francis.

Kachru, Yamura dan Larry E. Smith. 2008. Cultures, Contexts, and World Englishes New York: Routledge.

Kartomiharjo, Soeseno1988.. Bahasa Cermin Kehidupan Masyarakat. Jakarta: Dikbud.

Kramsch, Claire. 1998. Language and Culture. Oxford: Uxford University Press.

Mattulada. 1997. “Kebudayaan Bugis Makassar “. Dalam Manusia dan Kebudayaan di Indonesia. Koentjaraningrat. Jakartan Djembatan.

Saville-Troike, Muriel. 2003. The Ethnography of Communication: An Introduction. Third Edition. Oxford: Blackwell Publishing.

Sidi, Indra Djati dan Achmad D.S. 2003.Pembinaan Bahasa Indonesia dalam pendidikan di Lingkungan Direktorat Jenderal Pendidikan dasar dan Menegah dalam Kaitannya Dengan MABBIM, dalam Dendi Sugono (ed.), Bahasa Indonesia Menuju Masyarakat Madani. Jakarta: Pusat Bahasa, Departemen Pendidikan Nasional.

Suparno. 2003. Ketertiban Berbahasa sebagai Jembatan Menuju Peradaban Baru. Dalam dendi Sugono (ed.) Bahasa Indonesia Menuju Masyrakat Madani (Jakarta: Pusat Bahasa, Departemen Pendidikan Nasional.

Wijaya, I Dewa Putu. 1996. Dasar-dasar Pragmatik. Yogyakarta: Andi.

Yule, George. 1996. Pragmatics. Oxford New York: Oxford University Press. 
International Journal of Language Education and Culture Review 